\title{
KINEZITERAPIJOS PROGRAMŲ POVEIKIS LIGONIŲ PO KELIO SĄNARIO ENDOPROTEZAVIMO PUSIAUSVYRAI, KOJOS SKAUSMUI IR FUNKCIJAI
}

\section{Laura Urbanavičiūtė, Saulè Sipavičienė}

Lietuvos sporto universitetas

\section{SANTRAUKA}

Tyrimo pagrindimas. Didejant degeneracinių sąnarių ligų skaičiui, kelio sąnario endoprotezavimas yra labiausiai paplitusi procedūra, leidžianti efektyviai sumažinti skausmą ir tinkamai atgauti funkciją. Pooperaciniu laikotarpiu didžiąją reabilitacijos dalị užima kineziterapija, kuri daugelyje šalių yra pripažįstama kaip standartinis gydymas.

Tyrimo tikslas - ịvertinti skirtingų kineziterapijos programų poveikị ligonių po kelio sąnario endoprotezavimo pusiausvyrai, kojos skausmui ir funkcijai.

Metodai. Buvo tirta 20 asmenų, patyrusių kelio sąnario endoprotezavimo operaciją. Jie atsitiktiniu būdu suskirstyti ị 2 grupes: tiriamają (taikoma kineziterapija salejje ir vandenyje) ir kontrolinę (taikoma kineziterapija saleje). Funkcinių rodiklių testavimo metu buvo naudojama Vizualioji analogų skalè „VAS“, judesių amplitudès matuotos goniometru, raumenų jẻga vertinta Lowett’o skale, Tinetti testas (pusiausvyros ir eisenos) atliekamas reabilitacijos pradžioje ir pabaigoje.

Rezultatai. Po reabilitacijos pastebèti abiejų grupių tiriamųų statistiškai reikšmingi rodikliai. Po tyrimo skausmas sumažèjo abiejose grupèse po 4 balus $(\mathrm{p}<0,05)$. Kelio sąnario lenkimo amplitudè tiriamoje grupèje padidèjo 34 balais, kontrolinèje - 31 balu, tiesimo amplitudè tiriamojoje grupejje sumažèjo 6 balais, kontrolinejje -7 balais $(\mathrm{p}<0,05)$. Po reabilitacijos lenkiamujų raumenų jèga tiriamojoje grupejje padidejo 1 balu, kontrolinèje - 2 balais, tiesiamujų raumenų jèga abiejose grupèse padidèjo po 2 balus $(\mathrm{p}<0,05)$. Tiriamosios grupès pusiausvyra pagerèjo 7 balais, kontrolinès -8 balais $(\mathrm{p}<0,05)$. Tiriant ligonių eiseną po tyrimo pastebèta, kad eisenos rodikliai tiriamojoje grupeje pagerejo 7 balais, kontrolinejje -6 balais $(\mathrm{p}<0,05)$.

Išvados. Po kineziterapijos saleje ir kineziterapijos saleje kartu su vandens kineziterapija sumažèjo ligonių po kelio sąnario endoprotezavimo kojos skausmas, padidejjo raumenų jèga, kelio sąnario judesių amplitudè, pagerejo pusiausvyra ir eisena. Palyginus skirtingų kineziterapijos programų poveikị tarp abiejų grupių, reikšmingo skirtumo nenustatyta.

Raktažodžiai: kelio sąnario endoprotezavimas, kineziterapija vandenyje, kineziterapija salèje.

\section{IVADAS}

Judejjimo funkcija yra labai svarbi žmogaus gyvenime, tačiau dẻl gyventojų senejjimo ši funkcija pamažu sutrinka. Vienas iš dažniausių judejjimo funkcijos sutrikimų yra sąnarių skausmas. Varginančius skausmus, ypač kelio sąnaryje patiria net $80 \%$ gyventojų, ir tai sukelia judejimo ir mobilumo sutrikimus (Michael et al., 2010). Sutrikus sąnario veiklai, žmogus susiduria ne tik su medicininėmis, bet ir su socialinėmis, psichologinėmis problemomis. Dèl sutrikusios kelio sąnario funkcijos atsiranda skausmas, sumažèja judesių amplitudè, sutrinka žmogaus darbinė veikla, keičiasi ir gyvenimo būdas (Dovydènaitè, Drazdienè, 2016). 
Kineziterapijos programų poveikis ligonių po kelio sąnario endoprotezavimo pusiausvyrai, kojos skausmui ir funkcijai

Atlikta daug tyrimų, kuriais nustatyta, kad daugumai gyventojų kelio sąnario skausmas dažniausiai atsiranda dèl osteoartrito (OA). Osteoartritas yra labai paplitusi sąnarių liga, paveikianti 30-50\% suaugusiųu ( $\geq 60$ metų) (Sowers et al., 2009). Ši liga vystosi lètai, žmogus jaučiasi gerai gana ilgai, tačiau būklei progresuojant darosi sunku judèti, ima varginti nuolatinis skausmas labiausiai apkraunamuose sąnariuose. Labiausiai ši liga paplitusi tarp moterų ir vyresniojo amžiaus žmoniu (Singh, Sharma, 2018). Visame pasaulyje $9,6 \%$ vyrų ir $18,0 \% 60$ metų ir vyresnių moterų patiria simptomini osteoartritą (Health Quality Ontario, 2018).

Progresuojant sąnarių deformacijoms, didejjant skausmui, žmogui rekomenduojama endoprotezavimo operacija. Dèl šios patologijos kelio sąnarys yra vienas iš dažniausiai endoprotezuojamų sąnarių tiek Lietuvoje, tiek visame pasaulyje, ir šių operacijų poreikis nuolat didejja (Stučinskas ir kt., 2015). Kelio sąnario endoprotezavimo operacija atliekama esant vélyvoms osteoartrito stadijoms ir tada, kai konservatyvusis gydymas, reabilitacija ir medikamentinis gydymas nebeveiksmingi. Atlikus endoprotezavimą, skausmas ne tik sumažèja, bet ir atgaunama sąnario funkcija. Sąnarių endoprotezavimas yra pripažintas kaip vienas efektyviausias gydymo metodas (Aučynienė ir kt., 2014). Visgi po kelio sąnario pakeitimo pasekmès būna ịvairios - maždaug 15\% ligonių nepasiekia gero rezultato ir jaučia nuolatinị skausmą, turi judejjimo, pusiausvyros problemų, jų raumenų jèga būna apribota (Vadher et al., 2018).

Po endoprotezavimo operacijos kiekvienam ligoniui suteikiamas ambulatorinis gydymas. Pooperaciniu laikotarpiu didžiają reabilitacijos dalị apima kineziterapija, kuri taikoma iš karto po klubo ar kelio sąnarių endoprotezavimo, ir ji daugelyje šalių priimta kaip standartinis gydymas (Benz et al., 2015). Reabilitacijos metu labai svarbu daug dèmesio skirti fiziniams pratimams. Kineziterapija ne tik padeda sumažinti skausmą, bet ir pagerina funkciją, raumenų jègą, pusiausvyrą, sąnario stabilumą. Kineziterapijos procedūros yra labai rekomenduotinos po viso kelio sąnario pakeitimo operacijos. Atvykus ị reabilitaciją po operacijos, pagrindinis kineziterapijos tikslas - mobilizuoti, atgauti ir padidinti judesių amplitudes, sumažinti skausmą. Tolesnè kineziterapijos ir fizinių pratimų intervencija skatina mokymąsi ir funkcijos tobulèjimą (Artz et al., 2015). Jègos lavinimo pratimai atliekami ne tik palatoje ar kineziterapijos saleje, bet ir baseine. Vandenyje atliekami pratimai be galo naudinga procedūra, nes vanduo specifiškai veikia žmogaus organizmą. Plūdrumas mažina sąnarių apkrovą, todèl tai puiki alternatyva, nes atliekant pratimus saleje jaučiamas intensyvus skausmas. Pratimai vandenyje veiksmingiausi ankstyvose stadijose po endoprotezavimo operacijos, kai skausmas ir raumenu funkcijų sutrikimas riboja galimybę atlikti pasipriešinimo pratimus (Pozzi, 2013). Visgi vienas iš svarbiausių veiksnių, turinčių neigiamos įtakos pooperacinès reabilitacijos programoms, yra edema ir skausmas po kelio sąnario endoprotezavimo 
ankstyvuoju pooperaciniu laikotarpiu. Dėl edemos ir skausmo žmogaus funkcinis pajègumas sumažèja, taip pat ir galimybè pasiekti geresnių rodiklių (Oktas, Vergili, 2018). Todèl nepaprastai svarbu ankstyvos pooperacinès reabilitacijos metu nepamiršti edemos ir skausmo veiksnių. İrodyta, kad kineziterapija sumažina patinimą, padidina judesio spektrą, padidina jègą ir grąžina asmenims po kelio sąnario endoprotezavimo gerą funkciją (Masaracchio et al., 2017).

Tyrimo tikslas - ịvertinti skirtingų kineziterapijos programų poveikị ligonių po kelio sąnario endoprotezavimo pusiausvyrai, kojos skausmui ir funkcijai.

\section{METODAI}

Tiriamieji. Tyrimui atlikti gautas Lietuvos sporto universiteto Bioetikos komiteto leidimas. Buvo tiriama 20 asmenų (1 lent.), kuriems atlikta pilna kelio sąnario endoprotezavimo operacija. Tiriamieji atsitiktine tvarka suskirstyti ị dvi grupes po 10 žmonių. Tiriamajai grupei buvo taikoma kineziterapija salèje kartu su kineziterapija baseine, kontrolinei - tik kineziterapija salëje.

1 lentelè. Dviejų tiriamų grupių palyginimas

\begin{tabular}{|c|c|c|}
\hline \multirow{2}{*}{ Rodiklis } & \multicolumn{2}{|c|}{ Grupè } \\
\hline & Tiriamoji & Kontrolinè \\
\hline Lytis & $\begin{array}{l}8 \text { moterų } \\
2 \text { vyrų }\end{array}$ & $\begin{array}{c}8 \text { moterų } \\
2 \text { vyrų }\end{array}$ \\
\hline Amžius (metai \pm sn) & $67,3 \pm 4,9$ & $67,4 \pm 4,5$ \\
\hline Operuotas kelio sąnarys & $\begin{array}{c}6 \text { dešinysis } \\
4 \text { kairysis }\end{array}$ & $\begin{array}{c}5 \text { dešinysis } \\
5 \text { kairysis }\end{array}$ \\
\hline Ūgis $(\mathrm{cm} \pm \mathrm{sn})$ & $165,8 \pm 10,4$ & $165,2 \pm 8,3$ \\
\hline Svoris $(\mathrm{kg} \pm \mathrm{sn})$ & $61,8 \pm 9,9$ & $60,7 \pm 8,9$ \\
\hline
\end{tabular}

Tyrimo metodai. Abiejų grupių tiriamiesiems buvo atliekama 15 procedūrų (tris savaites kiekvieną dieną). Kiekvienos procedūros trukmė - 30-45 minučių. Kineziterapijos aktyvios ir pasyvios procedūros salèje buvo atliekamos abiejose grupèse 1 kartą per dieną 5 dienas po 30 minučių. Abiejų grupių tiriamiesiems buvo taikoma tokia pati kineziterapijos programa - naudojamas „Kinetec Performa with PU Pads" aparatas pasyviai kineziterapijai atlikti. Po pasyvios procedūros tiriamasis turejo atlikti aktyvią kineziterapiją gulèdamas ant kušetès, naudojant kineziterapines priemones, o atsistojęs atliko aktyvius pratimus su „Gym“ kamuoliu prie senelès, ant platformos, mindamas stacionarų dviratị. Tiriamajai grupei prie paprastos kineziterapijos po 15-kos dienų buvo pradèta taikyti aktyvi kinezitera- 
Kineziterapijos programų poveikis ligonių po kelio sąnario endoprotezavimo pusiausvyrai, kojos skausmui ir funkcijai

pija vandenyje, kuri trukdavo 25-30 minučių. Tiriamieji atliko aktyvius pratimus vandenyje - pasipriešinimo pratimus naudojant savo kūno svorị ir pagalbines priemones (vandens lazdas, vandens dviratị, vandens svarmenis ir ịvairias kitas papildomas mankštos priemones).

Kelio sąnario skausmo vertinimas VAS skale. Skausmas buvo matuojamas prieš atliekant aktyvius judesius. Tiriamasis apklausiamas žodžiu ir prašomas įvertinti skausmo stiprumo intensyvumą, lyginant su pačiu stipriausiu skausmu, kokị kada nors yra patyręs, skalèje nuo 0 (silpniausias) iki 10 (stipriausias) balų. Ligoniai ịvertino skausmą valdomoje kelio dalyje ir aplink ją.

Kelio sąnario amplitudes matavimas goniometru. Kelio sąnario judesių amplitudè matuojama standartiniu goniometru. Skale skaitoma nuo $0^{\circ}$ iki $180^{\circ}$. Judesys atliekamas sagitalioje plokštumoje apie medialinę-lateralinę ašị. Tiriamasis buvo testuojamas jam gulint ant nugaros, koja per kelio sąnarị ištiesta, klubo sąnario padètis neutrali.

Raumenu jegos manualinis testavimas. Raumenų jèga buvo matuojama 5 balu skale. Tiriamieji buvo testuojami jiems užimant gulimą padèti. Testuojant raumenų jègą, tiriamiesiems buvo nurodoma pradinè padètis ir paaiškinamas judesys, kurị jie turi atlikti, vertinama raumenu grupè.

Pusiausvyros Tinetti testas. Pirminè padètis: žmogus sèdi ant kietos kèdès, jo prašoma išlaikyti pusiausvyrą sẻdint, atsistoti iš sẻdimos padèties, išlaikyti pusiausvyrą pirmąsias $5 \mathrm{~s}$ po atsistojimo, atlaikyti stumtelejjimą (tiriamasis stovi suglaustomis pedomis, tyrẻjas lengvai stumteli delnu tiriamaji krūtinkaulio srityje 3 kartus), antrą kartą ligonio prašoma užsimerkti ir vèl lengvai stumtelëjama.

Eisenos Tinetti testas. Eisenos atlikimo technika: ligonio prašoma pereiti skersai kambarị - pirmyn ịprastu žingsniu ir grižzi atgal greitu, bet saugiu žingsniu. Buvo stebima tiriamojo ejjimo pradžia, žingsnio ilgis ir aukštis (abiejų pusių), žingsnių simetriškumas ir tolygumas, stebimas ligonio kūnas ir pėdų padètis.

Matematinė statistika. Duomenys apdoroti taikant „IBM SPSS Statistics 21 “ ir „Microsoft Excel 2010“ paketą. Buvo apskaičiuojamas kiekybinių rodiklių aritmetinis vidurkis, standartinis nuokrypis (SN). Kineziterapijos poveikiui vertinti buvo naudojami neparametriniai Mann'o-Whithey'aus kriterijai nepriklausomoms imtims ir Wilcoxon'o priklausomoms imtims lyginti. Nepriklausomų imčių Mann'o-Whithey'aus testas buvo taikomas lyginant nepriklausomas tiriamuju grupes (turinčius ir neturinčius nagrinėjamo požymio). Statistiškai reikšminga, kai $\mathrm{p}<0,05$. 


\section{TYRIMO REZULTATAI}

Po 3 savaičiu intervencijos, pritaikius skirtingas kineziterapijos priemones, skausmo intensyvumo rodikliai statistiškai reikšmingai $(p>0,05)$ sumažėjo abiejose tiriamujų grupèse (1 pav.).

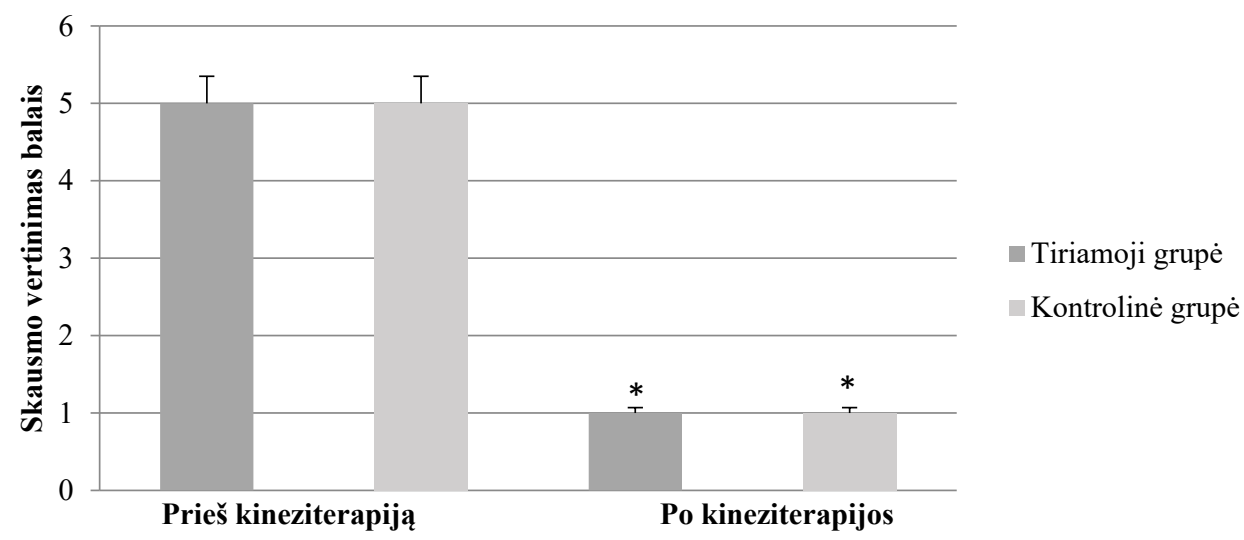

Pastaba. ${ }^{*}-\mathrm{p}<0,05$, lyginant rodiklius prieš kineziterapiją ir po jos.

1 pav. Tiriamų grupių operuotos kojos skausmo vertinimas prieš kineziterapiją ir po jos

Po 3 savaičių tyrimo pritaikius skirtingas kineziterapijos priemones, blauzdos lenkimo ir tiesimo amplitudès rodikliai statistiškai reikšmingai $(p>0,05)$ pagerejjo abiejose tiriamujų grupèse (2 lent.).

2 lentelè. Tiriamųjų operuotos kojos blauzdos lenkimo ir tiesimo amplitudès prieš kineziterapiją ir po jos

\begin{tabular}{|l|c|c|c|c|}
\hline \multirow{2}{*}{ Grupè } & \multicolumn{2}{|c|}{ Kelio sąnario lenkimas (laipsniai) } & \multicolumn{2}{c|}{ Kelio sąnario tiesimas (laipsniai) } \\
\cline { 2 - 5 } & $\begin{array}{c}\text { Prieš kinezi- } \\
\text { terapiją }\end{array}$ & Po kineziterapijos & $\begin{array}{c}\text { Prieš kinezite- } \\
\text { rapiją }\end{array}$ & $\begin{array}{c}\text { Po kinezitera- } \\
\text { pijos }\end{array}$ \\
\hline Tiriamoji & $63^{\circ}$ & $97^{\circ}$ & $-8^{\circ}$ & $-1^{\circ}$ \\
\hline Kontrolinė & $60^{\circ}$ & $91^{\circ}$ & $-9^{\circ}$ & $-1^{\circ}$ \\
\hline
\end{tabular}

Po 3 savaičiu tyrimo Tinetti testu buvo vertinama pusiausvyra - rodikliai statistiškai reikšmingai $(\mathrm{p}>0,05)$ pagerejjo abiejose grupèse (2 pav.). 
Kineziterapijos programų poveikis ligonių po kelio sąnario endoprotezavimo pusiausvyrai, kojos skausmui ir funkcijai

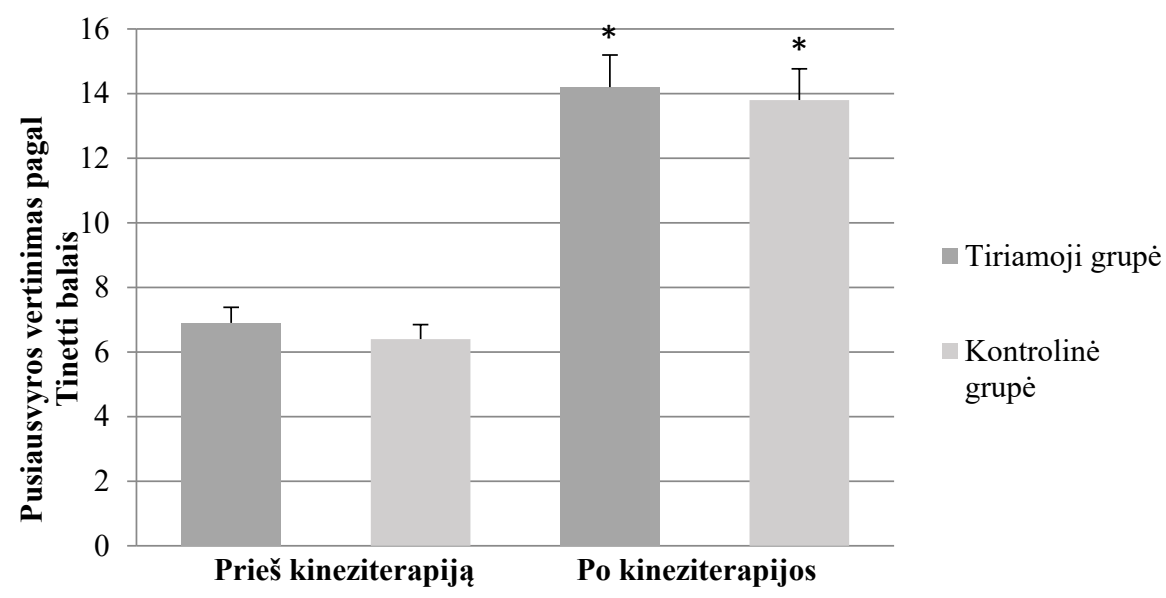

Pastaba. ${ }^{*}-\mathrm{p}<0,05$, lyginant rodiklius prieš kineziterapiją ir po jos.

2 pav. Tiriamų grupių ligonių pusiausvyros vertinimas pagal Tinetti skalę prieš kineziterapiją ir po jos

Po 3 savaičių tyrimo ligonių blauzdos lenkiamujų ir tiesiamujų raumenų jẻgos rodikliai statistiškai reikšmingai $(\mathrm{p}>0,05)$ pagerėjo abiejose grupėse (3 lent.)

3 lentelè. Tiriamụjų operuotos kojos blauzdos raumenų jèga prieš kineziterapiją ir po jos

\begin{tabular}{|l|c|c|c|c|}
\hline \multirow{2}{*}{ Grupė } & \multicolumn{2}{|c|}{$\begin{array}{c}\text { Blauzdos lenkiamujjų raumenų } \\
\text { jèga balais }\end{array}$} & $\begin{array}{c}\text { Blauzdos tiesiamųjų raumenų jèga } \\
\text { balais }\end{array}$ \\
\cline { 2 - 5 } & $\begin{array}{c}\text { Prieš kinezite- } \\
\text { rapiją }\end{array}$ & $\begin{array}{c}\text { Po kinezitera- } \\
\text { pijos }\end{array}$ & $\begin{array}{c}\text { Prieš kinezite- } \\
\text { rapiją }\end{array}$ & Po kineziterapijos \\
\hline Tiriamoji & 3 & 4 & 2,2 & 4 \\
\hline Kontrolinè & 2 & 4 & 2 & 4 \\
\hline
\end{tabular}

Po 3 savaičių tyrimo naudojantis Tinetti testu buvo vertinama ligonių eisena rodikliai statistiškai reikšmingai $(\mathrm{p}>0,05)$ pagerėjo abiejose grupėse (3 pav.). 


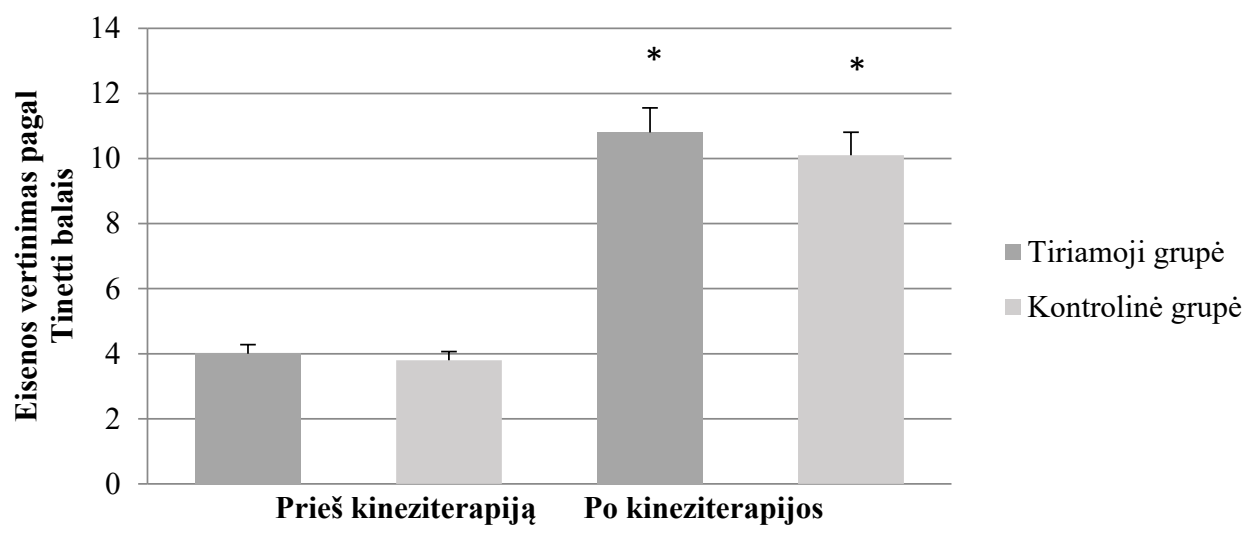

Pastaba. ${ }^{*}-\mathrm{p}<0,05$, lyginant rodiklius prieš kineziterapiją ir po jos.

3 pav. Tiriamųjų pusiausvyros vertinimas pagal

Tinetti skalę prieš kineziterapiją ir po jos

\section{REZULTATŲ APTARIMAS}

Tyrimo rodikliai parodè, kad po 3 savaičių kineziterapijos procedūrų sumažèjo skausmo intensyvumas, padidejo kelio sąnario blauzdos lenkimo ir blauzdos tiesimo judesių amplitudès, blauzdos lenkiamujų ir tiesiamujų raumenų jèga, pusiausvyra ir eisena reabilitacijos metu.Vertinant pritaikytas skirtingas kineziterapijos programas, pastebètas reikšmingas skirtumo pagerejjimas tik grupių viduje. Panašius duomenis gavo N. Gibson ir N. Shields (2015) - jos nustatė abiejų gydymo būdų rodiklių reikšmingą pagerējimą tiriamosios ir kontrolinès grupès viduje, tačiau tarp abiejų grupių reikšmingo skirtumo nebuvo.

Šio tyrimo rodikliai parodè, kad kineziterapijos salejje kartu su kineziterapija vandenyje derinys, palyginus su kineziterapijos salëje deriniu, buvo daug veiksmingesnis ir reikšmingesnis - greičiau atsigavo operuota koja, kelio sąnario judesių amplitudè ir raumenų jèga. T. Petkute ir E. Lendraitienè (2016) teigia, kad asmenims, kuriems taikyta kineziterapija vandenyje, tyrimo rodikliai buvo statistiškai reikšmingesni ir geresni nei tų, kuriems kineziterapija vandenyje nebuvo taikyta. Šis tyrimas padejo pamatyti ir nustatyti, kad kineziterapijos pratimai, taikomi vandenyje, gali labiau padidinti asmenų, kuriems atlikta endoprotezavimo operacija, kelio sąnario judesius bei amplitudę, sustiprinti raumenų jègos atsigavimą ir funkcinę būklę. Pagerējo abiejų grupių tiriamujų kelio sąnario blauzdos lenkimo ir tiesimo amplitudès, blauzdos lenkiamujų ir tiesiamujų raumenų jèga, sumažèjo 
Kineziterapijos programų poveikis ligonių po kelio sąnario endoprotezavimo pusiausvyrai, kojos skausmui ir funkcijai

skausmo intensyvumas. Greičiau pagerejo sąnario judesių amplitudės funkcija ir raumenų jèga bei sumažèjo esami patinimai tiems ligoniams, kuriems buvo taikyti kineziterapijos pratimai vandenyje, lyginant su kontroline grupe, kuriai taikyta tik kineziterapija saleje, bet ne vandenyje.

Po 3 savaičiu tyrimo skausmo intensyvumas sumažèjo abiejose grupèse. M. Łyp'as ir kt. (2016) tyrimu ịrodè, kad skausmo intensyvumo lygis pagal VAS ir Laitinen skalę buvo sumažintas abiejose gydymo grupèse, bet labiausiai sumažėjo ligoniams, kuriems taikyta kineziterapija saleje kartu su kineziterapija vandenyje. Analizuojant operuoto kelio sąnario judesių amplitudès intervalus, akivaizdus padidejimas ir didžiausias pokytis pastebètas po vandens procedūrų $(\mathrm{p}<0,001)$. Tiriamieji, kuriems buvo taikoma kineziterapija salejje kartu su kineziterapija vandenyje, pasiekè daug geresnių rezultatų nei kontrolinė grupè.

Mūsų tyrimo metu buvo siekiama ịvertinti pusiausvyrą ir eiseną naudojant Tinetti testą. Apžvelgus tyrimo rezultatus pastebeta, kad pusiausvyra ir eisena labiau pagerèjo tiriamojoje grupeje. Visgi statistiškai reikšmingo pokyčio tarp grupių nebuvo. R. López-Liria ir kt. (2015) tyrimo metu palygino dvi skirtingas programas: kineziterapiją namuose ir kineziterapiją ambulatorinejje ligoninejje. Jie taikè Tinetti testą ir pastebejjo kontrolinès grupès rodiklių pagerejjimą. Po reabilitacijos geresnès kelio sąnario blauzdos lenkimo ir tiesimo amplitudès bei blauzdos lenkiamujų ir tiesiamujų raumenų jèga pastebėta kontrolinèje grupejje, kurios tiriamiesiems reabilitacija buvo taikoma ambulatorinèje ligoninejje.

Apibendrinant tyrimo rezultatus ir palyginant juos su kitų autorių gautaisiais, galima teigti, kad taikytos skirtingos programos - kineziterapija salèje kartu su kineziterapija vandenyje ir tik kineziterapija saleje - yra efektyvios. Rodikliai parode, kad kineziterapijos pratimai ir procedūros saleje kartu su kineziterapija vandenyje buvo reikšmingai efektyvesnès atgaunant operuotos kojos kelio sąnario blauzdos lenkimo ir tiesimo amplitudes, kelio sąnario blauzdos lenkiamujų ir tiesiamujų raumenų jègą ir mažinant skausmo intensyvumą.

\section{IŠVADA}

Po kineziterapijos salèje ir kineziterapijos salëje kartu su kineziterapija vandenyje sumažèjo ligonių po kelio sąnario endoprotezavimo kojos skausmas, padidèjo raumenų jèga, kelio sąnario judesių amplitudè, pagerèjo pusiausvyra ir eisena. Palyginus skirtingų kineziterapijos programų poveikị tarp abiejų grupių rodiklių, reikšmingo skirtumas nenustatyta. 


\section{LITERATŪRA}

Artz, N., Elvers, K. T., Lowe, C. M. et al. (2015). Effectiveness of physiotherapy exercise following total knee replacement: Systematic review and meta-analysis. BMC Musculoskeletal Disorders, 16 (1), 15.

Aučynienė, L., Gadliauskaitè, A., Janonienė, D. (2014). Kineziterapijos programos taikymo ir gyvenimo kokybės sąsajos ligoniams po klubo sąnario endoprotezavimo. Gerontologija, 15 (1), 37-41.

Benz, T., Angst, F., Oesch, P. et al. (2015). Comparison of patients in three different rehabilitation settings after knee or hip arthroplasty: A natural observational, prospective study. BMC Musculosceletal Disorders, 16, 317.

Dovydènaite, J., Drazdienè, N. (2016). Impact of oral stimulation on feeding skills development in preterm infants. Sveikatos mokslai, 26 (3), 63.

Gibson, A. J., Shields, N. (2015). Effects of aquatic therapy and land-based therapy versus land-based therapy alone on range of motion, edema, and function after hip or knee replacement: A systematic review and metaanalysis. Physiotherapy Canada, 67 (2), 133-141.

Health Quality Ontario. (2018). Structured education and neuromuscular exercise program for hip and / or knee osteoarthritis: A health technology assessment. Ontario Health Technology Assessment Series, 18 (8), 1.

López-Liria, R., Padilla-Góngora, D., Catalan-Matamoros, D. et al. (2015). Home-based versus hospital-based rehabilitation program after total knee replacement. BioMed Research International, 1-9.

Łyp, M., Kaczor, R., Cabak, A. et al. (2016). A water rehabilitation program in patients with hip osteoarthritis before and after total hip replacement. Medical Science Monitor: International Medical Journal of Experimental and Clinical Research, 22, 2635.

Masaracchio, M., Hanney, W. J., Liu, X., Kolber, M., Kirker, K. (2017). Timing of rehabilitation on length of stay and cost in patients with hip or knee joint arthroplasty: A systematic review with meta-analysis. PloS One, 12 (6), e0178295.

Michael, J. W.-P., Schluter-Brust, K. U., Eysel, P. (2010). The epidemiology, etiology, diagnosis, and treatment of osteoarthritis of the knee. Deutsches Ärzteblatt International, 107 (9), 152-162.

Oktas, B., Vergili, O. (2018). The effect of intensive exercise program and kinesiotaping following total knee arthroplasty on functional recovery of patients. Journal of Orthopaedic Surgery and Research, 13 (1), 233.

Petkutè, T., Lendraitienė, E. (2016). Keturgalvio šlaunies raumens jègos lavinimo metodų taikymas asmenims po kelio sąnario endoprotezavimo. Reabilitacijos mokslai: slauga, kineziterapija, ergoterapija, 2 (15), $37-53$.

Pozzi, F., Snyder-Mackler, L., Zeni, J. (2013). Physical exercise after knee arthroplasty: A systematic review of controlled trials. European Journal of Physical and Rehabilitation Medicine, 49 (6), 877.

Singh, M., Sharma, A. R. (2018). An observational study-correlation of osteoarthritis knee with BMI, age and gender in a tertiary care hospital in Mullane, Ambala. International Journal of Scientific Research, 7 (2), $72-73$.

Sowers, M., Karvonen-Gutierrez, C. A., Palmieri-Smith, R. et al. (2009). Knee osteoarthritis in obese women with cardiometabolic clustering. Arthritis Care \& Research, 61 (10), 1328-1336.

Stučinskas, J., Bakevičius, M., Lebedev, A. et al. (2015). Lietuvos ligonių, sergančių kelio sąnario osteoartritu, rentgenologiniai šlaunikaulio parametrai ir jų reikšmẻ endoprotezavimo tikslumui. Sveikatos mokslai, 2 , $41-45$.

Vadher, K., Knight, R., Barker, K. L., Dutton, S. J. (2018). Community-based Rehabilitation after Knee Arthroplasty (CORKA): Statistical analysis plan for a randomised controlled trial. Trials, 19 (1), 638. 
Kineziterapijos programų poveikis ligonių po kelio sąnario endoprotezavimo pusiausvyrai, kojos skausmui ir funkcijai

\section{EFFECT OF DIFFERENT PHYSIOTHERAPY PROGRAMS ON BALANCE, LIMB PAIN AND FUNCTION AFTER KNEE JOINT ENDOPROSTHESIS}

\section{Laura Urbanavičiūtè, Saulè Sipavičienè}

Lithuanian Sports University

\section{ABSTRACT}

Background. Since the number of degenerative joint diseases has been increasing, knee replacement surgery is the most common procedure for effectively reducing pain and restoring THE function properly. In postoperative care, most rehabilitation involves physiotherapy immediately following knee replacement surgery, which is accepted as a standard treatment in most countries.

Research aim was to evaluate the effects of different physiotherapy programs on balance and limb pain and function after knee joint endoprosthesis.

Methods. The study involved 20 participants after knee joint endoprosthesis surgery. They were randomly divided into 2 groups: experimental group (physiotherapy applied in the room and in water) and control group (physiotherapy applied in the room). The average age of the experimental group was $67.3 \pm 4.9 \mathrm{~m}$, while the average age of control group was $67.4 \pm 4.5 \mathrm{~m}$, according to other factors the groups were homogeneous. Testing of functional factors was performed at the beginning and the end of rehabilitation. During functional indicators testing, Visual Analog Scale "VAS" was used, goniometer for motion amplitude measurement, muscle strength assessment on Lowett scale, Tinetti test (equilibrium and gait) were performed at the beginning and the end of rehabilitation.

Results. After rehabilitation, statistically significant results of both groups were obvious. After the study, the pain decreased in both groups by 4 points $(p<0.05)$. Range of motion at the knee joint flexion increased in the experimental group by 34 points and in the control group by 31 points, at the knee joint extension - in the experimental group it decreased by 6 points, in the control group by 7 points $(\mathrm{p}<$ $0.05)$. After the rehabilitation, the strength of the flexural muscles in the experimental group increased by 1 point, and in the control group by 2 points, the muscle strength in both groups increased by 2 points $(p<0.05)$. The balance of the experimental group increased by 7 points and that of the control group by 8 points $(\mathrm{p}<$ $0.05)$. Patient progression after the research showed that the gait results improved 
for the experimental group by 7 points and for the control group by 6 points $(\mathrm{p}<$ $0.05)$.

Conclusion. After physiotherapy in the room and physiotherapy in the room with water physiotherapy, limb pain decreased, muscle strength and range of motion at knee joint increased, the balance and gait improved after knee joint endoprosthesis surgery. Comparing the effects of different physiotherapy programs between both groups the difference in significance were not observed.

Keywords: knee joint endoprosthesis, physiotherapy in water, osteoarthritis, physiotherapy.

Gautas 20190801

Priimtas 20191025 